\title{
The direct role of enzyme hydrolysis on ammonium regeneration rates in estuarine sediments
}

\author{
Afonso C. Souza ${ }^{1}$, Tamara K. Pease ${ }^{2}$, Wayne S. Gardner ${ }^{1, *}$ \\ ${ }^{1}$ The University of Texas at Austin, Marine Sciences Institute, 750 Channel View Drive, Port Aransas, Texas 78373, USA \\ ${ }^{2}$ The University of Texas at Brownsville, Chemistry and Environmental Science, 80 Fort Brown Brownsville, Texas 78520, USA
}

\begin{abstract}
Benthic ammonium $\left(\mathrm{NH}_{4}^{+}\right)$regeneration in coastal marine sediments has a fundamental role in nitrogen $(\mathrm{N})$ cycling and $\mathrm{N}$ supply to primary producers. Nitrogen regeneration involves benthic microbial mineralization of organic-N, which, in turn, depends on protein hydrolysis. These processes were examined in Aransas Bay (Texas, USA) sediments by monitoring $\mathrm{NH}_{4}{ }^{+}$ evolution as a function of enzyme activity in controlled sediment slurries. Casein and tannic acid were added to evaluate the direct role of aminopeptidase on $\mathrm{NH}_{4}{ }^{+}$production and the effects of a polyphenolic enzyme inhibitor, respectively. Casein additions increased the $\mathrm{NH}_{4}{ }^{+}$concentration from $19 \pm 0.3$ to $737 \pm 150 \mu \mathrm{M}$ in $120 \mathrm{~h}$, a final concentration 4.3-fold higher than that of control samples and 2.9-fold higher than that of samples with casein and tannic added together. Lower $\mathrm{NH}_{4}{ }^{+}$concentration in samples with tannic acid indicated that inhibiting aminopeptidase activity reduced $\mathrm{NH}_{4}{ }^{+}$production rates. The concentration of the regenerated $\mathrm{NH}_{4}{ }^{+}$related directly to aminopeptidase activity in controls $(r=0.86, p<0.01)$, casein-enriched $(r=0.89, p<0.01)$, and casein plus polyphenol treatments $(r=0.71, p<0.01)$ over the first $72 \mathrm{~h}$. The results demonstrate the importance of aminopeptidase in regenerating $\mathrm{NH}_{4}{ }^{+}$in sediments and provide insights about mechanisms of enzyme hydrolysis and $\mathrm{NH}_{4}{ }^{+}$fluxes in estuarine sediments.
\end{abstract}

KEY WORDS: Leucine-aminopeptidase - Extracellular enzymes - Ammonium regeneration · Marine sediments

Resale or republication not permitted without written consent of the publisher

\section{INTRODUCTION}

Estuarine productivity is linked to the input of nutrients from freshwater inflow or biological regeneration processes (D'Elia et al. 1986). Rivers typically are a major source of nutrients to estuaries (Nielsen et al. 2002, Paerl et al. 2002), but, in some cases, the quantities of nutrients supplied by benthic regeneration resemble or exceed amounts originating from rivers (Fisher et al. 1982, Boynton \& Kemp 1985, Cowan \& Boynton 1996). Internal recycling is therefore an important component of estuaries with low freshwater inflow, where the nutrient supply can be insufficient to fulfill the demand of primary producers (Boyer et al. 1988). South Texas estuaries, for example, have restricted freshwater inflows due to the local sub-tropical, semi-arid climate. This region experiences prolonged droughts, and significant riverine water inputs depend on short-lived pulses following storm events. As a result, local estuaries have long water residence times and benthic regeneration of nutrients becomes a significant source of nutrients (Bianchi et al. 1999, Gardner et al. 2006). Corpus Christi Bay waters, for example, have frequent ammonium $\left(\mathrm{NH}_{4}^{+}\right)$concentration increases in late summer resulting from temperature-induced intensification of benthic organic matter $(\mathrm{OM})$ remineralization (Bianchi et al. 1999) or dissimilatory nitrate reduction to $\mathrm{NH}_{4}{ }^{+}$(An \& Gardner 2001, Gardner et al. 2006, McCarthy et al. 2008).

In coastal environments, nitrogen $(\mathrm{N})$ remineralization often occurs in the sediment (Warnken et al. 2000). Ammonium is the dominant reactive $\mathrm{N}$ species in the porewater (Berman \& Bronk 2003), and its 
efflux from the sediment depends on benthic microbial mineralization (Kemp \& Boynton 1984), which, in turn, depends in part on protein hydrolysis (Blackburn \& Henriksen 1983, Henriksen \& Kemp 1988, Galloway et al. 2004). Variations of $\mathrm{NH}_{4}{ }^{+}$concentration in the environment may relate to the types and supply rates of bioavailable organic-N. Proteins derived from phytoplankton can be metabolized, and high $\mathrm{NH}_{4}{ }^{+}$regeneration rates have been associated with phytoplankton production (Gardner et al. 1993, 1996). Prokaryotes, however, need to hydrolyze proteins and peptides into amino acids to allow transport of organic- $\mathrm{N}$ across their membranes prior to intracellular deamination resulting in $\mathrm{NH}_{4}{ }^{+}$production (Jaffe 2000), which indicates that enzymes must be involved in $\mathrm{NH}_{4}{ }^{+}$regeneration by bacteria (Jacobson et al. 1987).

Enzyme hydrolysis influences fluxes of $\mathrm{N}$ between sources and sinks in coastal environments, and relates to global $\mathrm{N}$ budget issues. Benthic $\mathrm{NH}_{4}{ }^{+}$production relates to the supply and quality of $\mathrm{OM}$ (Blackburn 1991). For example, a large portion of organic- $\mathrm{N}$ deposited in estuarine sediments is recycled to $\mathrm{NH}_{4}{ }^{+}$by bacteria (Wollast 1991, Hansen \& Blackburn 1992). The dependence of $\mathrm{NH}_{4}{ }^{+}$production on the availability of organic substrate is suggested by a direct relationship between dissolved free amino acid (DFAA) availability and sediment $\mathrm{NH}_{4}{ }^{+}$concentration (Hansen et al. 1993) and the regulation of intracellular enzymatic pathways based on $\mathrm{N}$ availability (Leigh \& Dodsworth 2007). Most organic matter remaining in sediments is polymeric and unavailable to microbial metabolism without initial enzymatic hydrolysis (Arnosti 2011). Assuming that many free amino acids consumed in nature are produced from protein hydrolysis, this link between amino acid availability and $\mathrm{NH}_{4}{ }^{+}$production suggests that aminopeptidase is involved in the $\mathrm{NH}_{4}{ }^{+}$ regeneration process. The production of amino acids by aminopeptidase has been observed in environmental samples (Cowie \& Hedges 1992, Pantoja et al. 1997, Pantoja \& Lee 1999). The present work examines links between $\mathrm{NH}_{4}{ }^{+}$production and aminopeptidase activity, based on the hypothesis that much of the $\mathrm{NH}_{4}{ }^{+}$production in marine sediments is preceded by amino acid formation (Wollast 1993, Landen \& Hall 1998) and depends on proteolytic enzyme activities (Cowie \& Hedges 1992, Pantoja et al. 1997, Pantoja \& Lee 1999). A coupling between aminopeptidase activity and $\mathrm{NH}_{4}{ }^{+}$production is probable, but has not been established in marine sediments. A direct relationship between proteolytic enzymatic reactions and regeneration of $\mathrm{NH}_{4}{ }^{+}$in marine sedi- ments would underscore the role of enzymes in OM decomposition and provide evidence of their direct role on nutrient regeneration.

\section{MATERIALS AND METHODS}

\section{Sediment sampling and preparation}

Sediment samples were collected in Aransas Bay, Texas, USA, at a $1.5 \mathrm{~m}$ water depth in February 2008 and April 2008. Water temperature was $24^{\circ} \mathrm{C}$ during both sampling trips. Water salinity was 18 in February and 25 in April. Sediment cores were collected in Plexiglas tubes with an inner diameter of $7.7 \mathrm{~cm}$. Six sediment cores were taken to the laboratory and sectioned to sub-sample the sediment layer between 5 and $10 \mathrm{~cm}$. Sediment in this layer was assumed to be anoxic based on distinct coloration differences from the top centimeter, as well as its sulfide odor. These $5 \mathrm{~cm}$ sediment sections from the respective cores were combined and homogenized in pre-combusted glass beakers. Aliquots $90 \mathrm{ml}$ of the homogenized wet sediment were transferred into $100 \mathrm{ml}$ glass serum bottles using a $10 \mathrm{ml}$ truncated syringe. $\mathrm{N}_{2}$-purged bottom water $90 \mathrm{ml}$ was added to each bottle to prepare 1:1 slurries by volume. Each slurry bottle was capped with a rubber stopper, crimpsealed gas-tight, and flushed with $\mathrm{N}_{2}$ gas to maintain the slurry under anoxic conditions during the incubation period at ca. in situ temperature.

\section{Experiment 1}

The experiment to measure $\mathrm{NH}_{4}{ }^{+}$production and aminopeptidase activity in February 2008 included 3 replicate slurries per treatment. The control treatment consisted of seawater alone, whereas the casein sediment-slurry treatment received $5 \mu \mathrm{g} \mathrm{ml}^{-1}$ casein, and the casein-plus-polyphenol sediment-slurry treatment received $5 \mu \mathrm{g} \mathrm{ml}^{-1}$ casein and $50 \mathrm{\mu g} \mathrm{g}^{-1}$ of tannic acid, a common standard for polyphenols (van Alstyne 1995). The polyphenol concentration was based on previous experiments on polyphenol inhibition of aminopeptidase activity (data not shown). Slurries were incubated at room temperature in crimp-sealed serum bottles. Five milliliter seawater aliquots were taken for $\mathrm{NH}_{4}{ }^{+}$analysis at time points of $0,4,24,48$, and $72 \mathrm{~h}$, using $10 \mathrm{ml}$ syringes. The seawater samples were filtered through $0.2 \mu \mathrm{m}$ syringe filters, and the filtrate was transferred to $10 \mathrm{ml}$ glass vials for storage at $-20^{\circ} \mathrm{C}$ until the last day of the time 
series. Slurry seawater $\mathrm{NH}_{4}{ }^{+}$concentration was measured at an absorbance of $640 \mathrm{~nm}$ after chemical chromatophore formation (Parsons et al. 1984).

Aminopeptidase activity was measured in slurries consisting of $1 \mathrm{ml}$ wet sediment and $1 \mathrm{ml}$ core seawater by adding an enzyme analog (L-leucine 7 -amido4 -methylcoumarin) to slurries to provide a final concentration of $250 \mu \mathrm{M}$ in the slurry (Hoppe 1983). Three slurries per treatment were prepared for each time point. Slurries were prepared using $10 \mathrm{ml}$ truncated syringes to dispense the $1 \mathrm{ml}$ sediment samples into $50 \mathrm{ml}$ glass serum bottles. Slurry bottles were capped with rubber stoppers, crimp-sealed, and flushed with $\mathrm{N}_{2}$ gas to maintain anoxic conditions during the incubation period. Slurry samples were discarded at time points $0,4,24,48$, and $72 \mathrm{~h}$ to measure aminopeptidase enzyme activity.

A 2-sample $t$-test was performed to determine whether the $\mathrm{NH}_{4}{ }^{+}$concentrations at each time point were different among treatments. This test compared the means of each time point among treatments with unequal variance. The degree of linear association between enzyme activity and $\mathrm{NH}_{4}{ }^{+}$concentration in each treatment was determined from a Pearson correlation coefficient. All statistical analyses were performed using MINITAB-15 statistical software.

\section{Experiment 2}

The experiment in April 2008 was designed to measure $\mathrm{NH}_{4}{ }^{+}$concentration changes with time in 4 treatments and to examine the effects of adding tannic acid, a polyphenolic enzyme inhibitor. The control treatment consisted of 1:1 sediment-seawater without any substrate or polyphenol amendments. The other treatments were sediment slurries amended with $100 \mu \mathrm{g} \mathrm{ml}^{-1}$ casein, $100 \mu \mathrm{g} \mathrm{g}^{-1}$ of tannic acid, and a combination of $100 \mu \mathrm{g} \mathrm{ml}^{-1}$ casein and $100 \mu \mathrm{g} \mathrm{g}^{-1}$ tannic acid, respectively. Aminopeptidase activity was determined as described in the previous section 'Experiment 1' for the February 2008 section; however, additions of casein and polyphenols to slurries were $100 \mu \mathrm{g} \mathrm{ml}^{-1}$ casein and $100 \mu \mathrm{g} \mathrm{g}^{-1}$ polyphenols.

Sediment slurries were enriched with increasing casein concentrations of $0,50,100$, and $150 \mu \mathrm{g}$ casein $\mathrm{ml}^{-1}$, respectively, to determine whether the $\mathrm{NH}_{4}{ }^{+}$ production rate related directly to protein content. Triplicate respective mixtures of $40 \mathrm{~cm}^{3}$ wet sediment, and $40 \mathrm{ml}$ filtered core water ratio (v/v), were prepared per casein concentration. Slurries were incubated at room temperature in gas-tight serum glass bottles under anoxic conditions. A $5 \mathrm{ml}$ seawa- ter aliquot was sampled using a $5 \mathrm{ml}$ syringe with a needle from each slurry bottle, when the slurries were crimp-sealed and again at the end of the $96 \mathrm{~h}$ incubation period. The $5 \mathrm{ml}$ seawater aliquots were filtered through $0.2 \mu \mathrm{m}$ pore size syringe filters, and the filtrate was stored at $-20^{\circ} \mathrm{C}$ in capped glass vials for $5 \mathrm{~d}$ until colorimetric analysis according to Parsons et al. (1984).

\section{RESULTS}

\section{Ammonium production and enzyme activity}

Samples collected from Aransas Bay in February 2008 were treated with casein and polyphenol, and incubated for $72 \mathrm{~h}$ to examine $\mathrm{NH}_{4}{ }^{+}$evolution. Initial $\mathrm{NH}_{4}{ }^{+}$concentration averaged $55 \pm 0.6 \mu \mathrm{M}$ in all treatments and almost doubled within about $4 \mathrm{~h}$ of incubation (Fig. 1). Increases in $\mathrm{NH}_{4}{ }^{+}$concentration were slower during the remaining incubation times. Ammonium in the casein treatment accumulated to $130 \pm 0.1 \mu \mathrm{M}$ in $72 \mathrm{~h}$, and the net $\mathrm{NH}_{4}{ }^{+}$concentration change of $75 \mu \mathrm{M}$ accounted for $63 \%$ of the casein-N added. The final $\mathrm{NH}_{4}{ }^{+}$concentrations were $108 \pm 1.0$ and $107 \pm 0.6 \mu \mathrm{M}$ in the control and polyphenol treatments, respectively. Ammonium concentrations were similar in the control and the casein-plus-polyphenol treatments at each time point. On the other hand, significantly higher concentrations of $\mathrm{NH}_{4}{ }^{+}$were measured in casein-enriched samples at 48 and $72 \mathrm{~h}$ (2-sample $t$-test, $\mathrm{p}<0.01$ ).

Aminopeptidase activity increased with time in all treatments (Fig. 2). Enzyme activity in controls

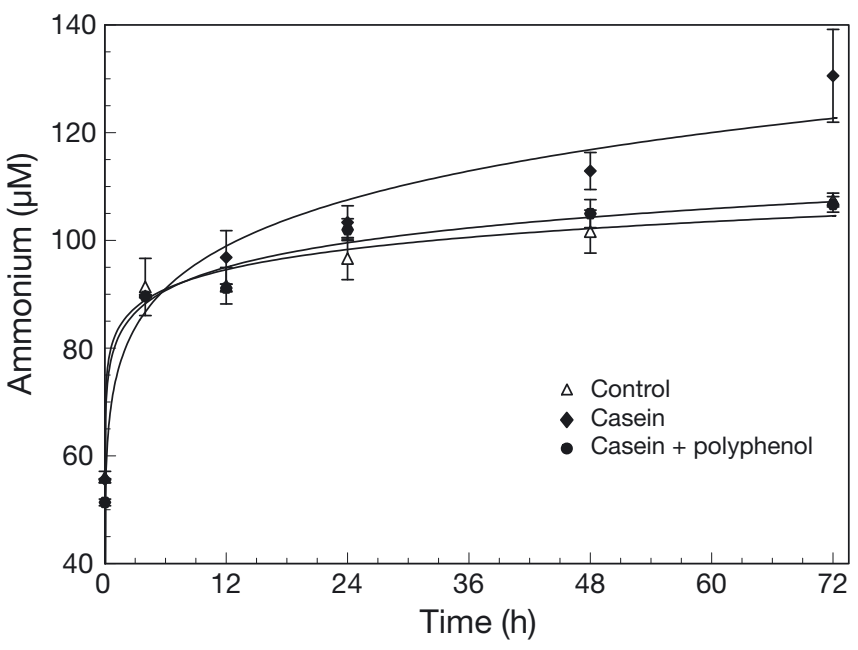

Fig. 1. Ammonium evolution through time in Aransas Bay (Texas, USA) sediment slurries, February 2008. Error bars are $95 \%$ confidence intervals of $n=3$ 


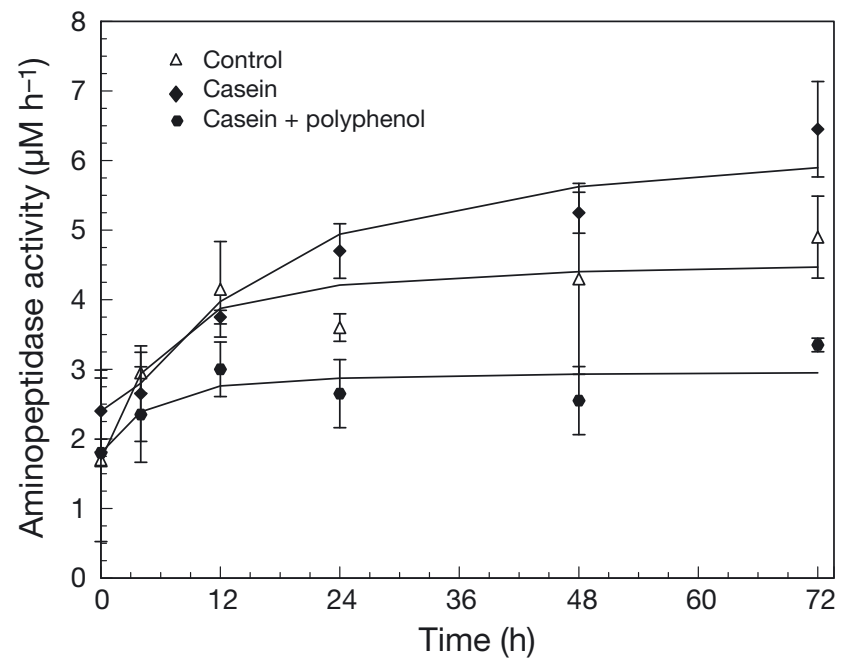

Fig. 2. Aminopeptidase activity as a function of time in Aransas Bay sediment slurries, February 2008. Error bars are $95 \%$ confidence intervals of $n=3$

increased from $1.7 \pm 1.0$ to $4.9 \pm 0.6 \mu \mathrm{M} \mathrm{h}^{-1}$ within $72 \mathrm{~h}$ as compared to from $2.4 \pm 0.6$ to $6.5 \pm 0.7 \mu \mathrm{M}$ $\mathrm{h}^{-1}$ in casein-amended samples. Enzyme activity increased from $1.8 \pm 0.2$ to $3.4 \pm 0.1 \mu \mathrm{M} \mathrm{h}^{-1}$ in samples treated with polyphenols. After the first $24 \mathrm{~h}$ of incubation, enzyme activity remained lower, at each time point, in samples treated with a combination of casein and polyphenol than in those of the other 2 treatments $(p<0.01)$. The activity of casein-enriched samples was highest among treatments at time points 24,48 , and $72 \mathrm{~h}(\mathrm{p}<0.01)$. The average rate of hydrolysis for the samples amended with casein was $4 \mathrm{\mu M} \mathrm{h}^{-1}$ in $72 \mathrm{~h}$ of incubation, which could produce potentially $288 \mu \mathrm{M}$ of hydrolyzate during that time interval. However, the net concentration of $\mathrm{NH}_{4}{ }^{+}$produced was $75 \mu \mathrm{M}$ over the same period.

The increases in $\mathrm{NH}_{4}{ }^{+}$concentration correlated positively with enzyme activity in all 3 treatments (Fig. 3). The Pearson coefficient of linear association (r) between $\mathrm{NH}_{4}{ }^{+}$and aminopeptidase activity was $0.86,0.89$, and 0.71 for the control, casein, and casein- plus-polyphenol treatments, respectively. The $\mathrm{p}$-values of all correlations between $\mathrm{NH}_{4}{ }^{+}$concentration and enzyme activity were $<0.01$.

\section{Ammonium production and casein concentration}

Organic-N constitutes a significant part of the total fixed $\mathrm{N}$ in estuaries (Berman \& Bronk 2003). Casein was added in $50 \mu \mathrm{g} \mathrm{ml}^{-1}$ increments (up to $150 \mu \mathrm{g}$ $\mathrm{ml}^{-1}$ ) to Aransas Bay sediment slurries to examine the potential relationship between protein substrate
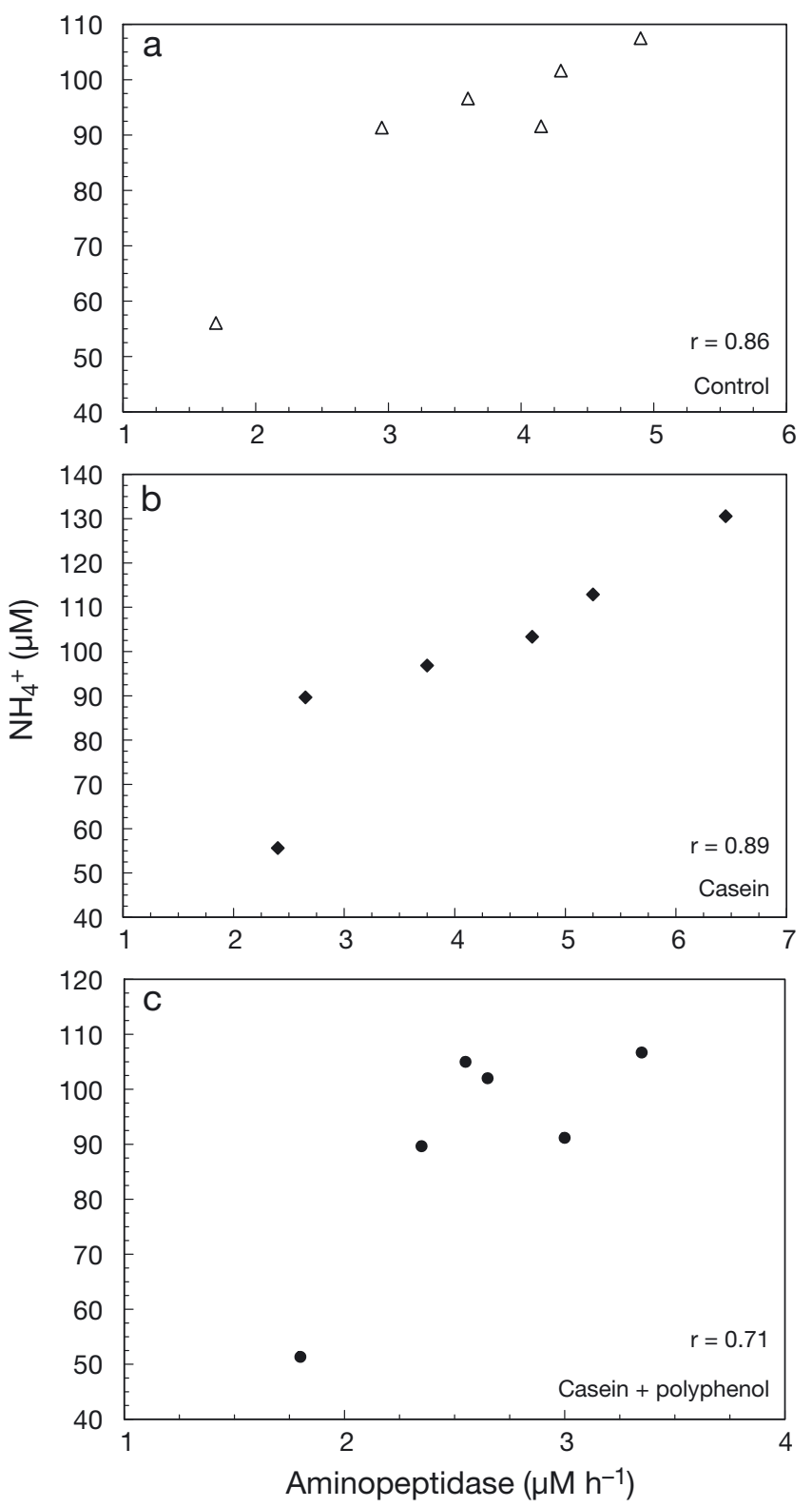

Fig. 3. Linear correlations between ammonium concentration and aminopeptidase activity in (a) control, (b) casein, and (c) casein + polyphenol treatments, February 2008. r: Pearson's correlation coefficient

added and $\mathrm{NH}_{4}{ }^{+}$released (Fig. 4). The $\mathrm{NH}_{4}{ }^{+}$produced increased proportionally with casein concentration at a rate of approximately $200 \mu \mathrm{M} \mathrm{NH}_{4}{ }^{+}$per $50 \mu \mathrm{g} \mathrm{ml}^{-1}$ casein substrate. The significant linear regression $\left(\mathrm{r}^{2}\right.$ $=0.99$ ) quantified this relationship and confirmed that the potential amount of $\mathrm{NH}_{4}{ }^{+}$released was related to the concentration of available organic-N (casein).

$\mathrm{NH}_{4}{ }^{+}$evolution was monitored in sediment slurries containing tannic acid, a polyphenol that is an enzyme inhibitor (Thurman 1985), to evaluate the role 


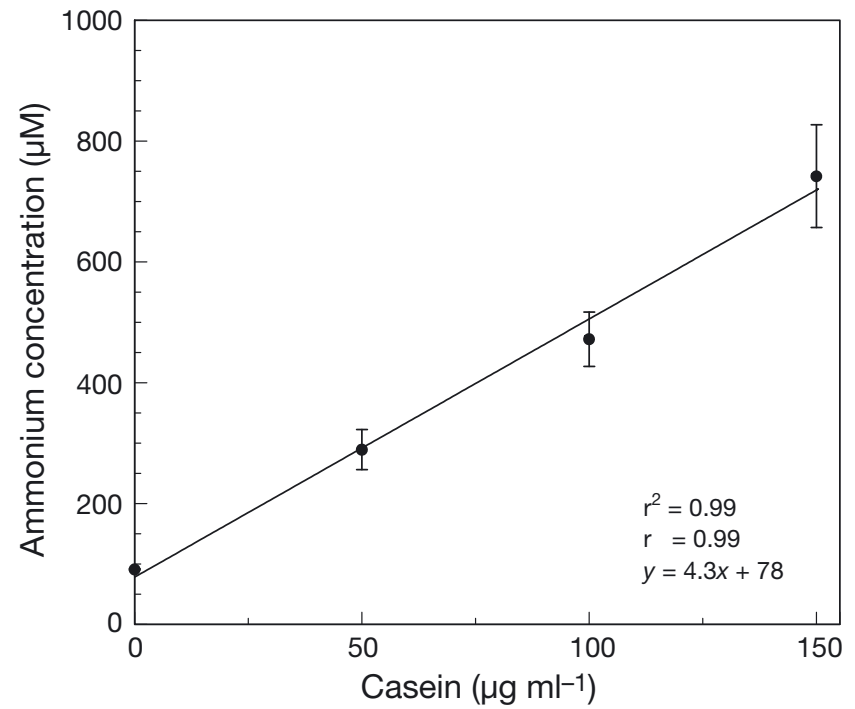

Fig. 4. Linear relationship between organic nitrogen substrate (casein) and ammonium concentration, February

2008. Error bars are $95 \%$ confidence intervals of $n=3$

of aminopeptidase on $\mathrm{NH}_{4}{ }^{+}$production in April 2008. In control samples, $\mathrm{NH}_{4}{ }^{+}$concentration reached $59 \pm$ $8 \mu \mathrm{M}$ in $96 \mathrm{~h}$ at a rate $0.5 \mu \mathrm{M} \mathrm{NH}_{4}{ }^{+} \mathrm{h}^{-1}$. The addition of casein increased the $\mathrm{NH}_{4}{ }^{+}$concentration from $14 \pm$ 2 to $632 \pm 28 \mu \mathrm{M}$ by the end of the incubation period (Fig. 5). The net $\mathrm{NH}_{4}{ }^{+}$concentrations produced indicated that $26 \%$ of the $\mathrm{N}$ from casein was regenerated as $\mathrm{NH}_{4}{ }^{+}$. The overall rate of increase was approximately $6.4 \mu \mathrm{M} \mathrm{NH}_{4}{ }^{+} \mathrm{h}^{-1}$ during the $96 \mathrm{~h}$ incubation period $\left(r^{2}=0.93\right)$, which was 13-fold faster than the rate estimated in unamended control samples. In

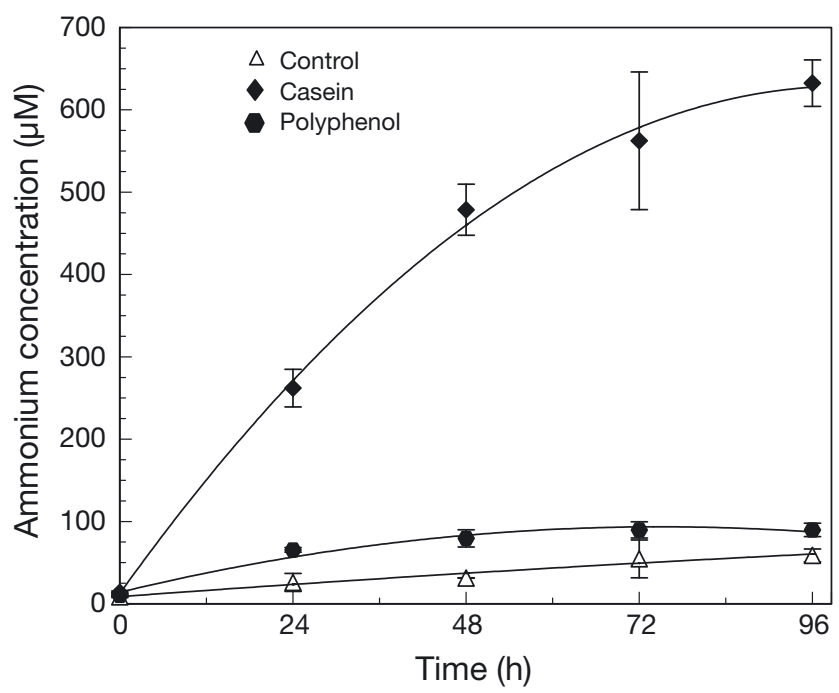

Fig. 5. Ammonium concentration as a function of time in Aransas Bay sediment, April 2008. Error bars are $95 \%$ confidence intervals of $\mathrm{n}=3$ samples treated with polyphenol, the $\mathrm{NH}_{4}{ }^{+}$concentration reached $89 \pm 7 \mu \mathrm{M}$ in $96 \mathrm{~h}$, slightly higher than in controls ( $t$-test, $\mathrm{p}=0.01)$.

The pattern of aminopeptidase activity with time was not linear (Fig. 6). In control samples, enzyme activity peaked from an initial value of $1.1 \pm 0.1$ to 3.2 $\pm 0.7 \mu \mathrm{M} \mathrm{h}^{-1}$ in $48 \mathrm{~h}$, followed by a decrease to $1.2 \pm$ $1.0 \mu \mathrm{M} \mathrm{h}^{-1}$ by the end of the incubation period. In casein-enriched samples, the enzyme activity of $4.7 \pm$ $0.1 \mu \mathrm{M} \mathrm{h}^{-1}$, reached at $48 \mathrm{~h}$, was significantly higher than that of controls (2-sample $t$-test, $\mathrm{p}=0.02)$. In the polyphenol treatment, the pattern of activity was similar to that of the control. Activity increased from $1.5 \pm 0.3 \mu \mathrm{M} \mathrm{h}^{-1}$ at the beginning of the incubation to $3.2 \pm 0.2 \mu \mathrm{M} \mathrm{h}^{-1}$ after $48 \mathrm{~h}$ and then returned to $1.5 \pm$ $0.3 \mu \mathrm{M} \mathrm{h}^{-1}$ by the end of the incubation.

An additional experiment to measure $\mathrm{NH}_{4}{ }^{+}$evolution in the presence of tannic acid was conducted to examine the causal relationship between $\mathrm{NH}_{4}{ }^{+}$concentration and aminopeptidase activity. Ammonium concentrations increased over time in all treatments (Fig. 7). The net $\mathrm{NH}_{4}{ }^{+}$concentrations in caseinenriched samples indicated that about $30 \%$ of casein-N added was regenerated. After $120 \mathrm{~h}$ of incubation, casein additions increased the $\mathrm{NH}_{4}{ }^{+}$concentration from $19 \pm 0.3$ to $737 \pm 150 \mu \mathrm{M}$, a final concentration 4.3-fold higher than that of control samples and 2.9-fold higher than that of samples with casein and tannic acid added together (2-sample $t$ test, $\mathrm{p}<0.01$ ). The addition of this polyphenol to casein-enriched samples lowered the $\mathrm{NH}_{4}{ }^{+}$production rate by 1.5 -fold. Cumulative $\mathrm{NH}_{4}{ }^{+}$concentration

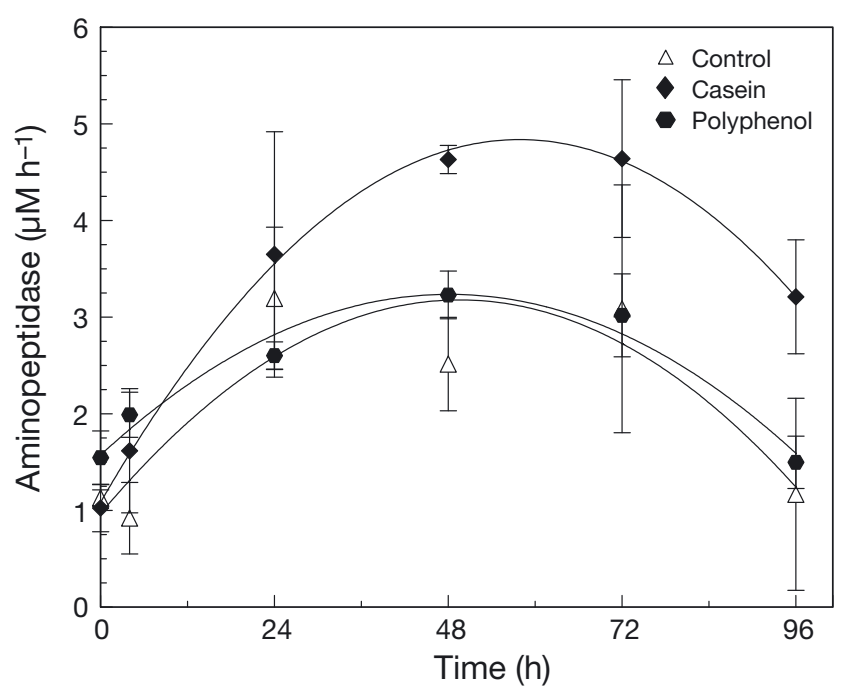

Fig. 6. Aminopeptidase activity as a function of time in Aransas Bay sediment, April 2008. Error bars are 95\% confidence intervals of $n=3$ 


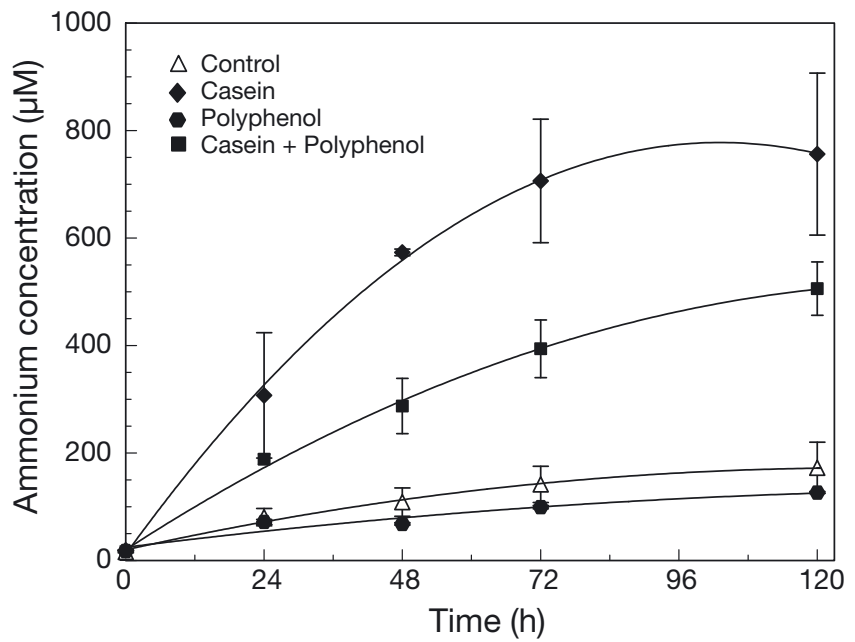

Fig. 7. Ammonium concentration in the presence of tannic acid as a function of time in Aransas Bay, April 2008. Error bars are $95 \%$ confidence intervals of $n=3$

after $120 \mathrm{~h}$ was 1.5 times lower in samples where casein was combined with polyphenol than in samples with casein alone $(\mathrm{p}<0.01)$.

\section{DISCUSSION}

\section{Ammonium production and enzyme activity}

The goal of this work was to determine whether $\mathrm{NH}_{4}{ }^{+}$production is coupled to aminopeptidase activity and protein concentration. The hypothesis proposed was that $\mathrm{NH}_{4}{ }^{+}$production in marine sediments depends on aminopeptidase activity. The results showed that an increase in enzyme activity, associated with the addition of organic nitrogenous substrate, caused an increase in the $\mathrm{NH}_{4}^{+}$production rate. In addition, the presence of an aminopeptidase inhibitor reduced the $\mathrm{NH}_{4}{ }^{+}$production rate. Thus, the regeneration of $\mathrm{NH}_{4}{ }^{+}$in the sediment relates to aminopeptidase activity. The dependence of $\mathrm{NH}_{4}^{+}$ production on aminopeptidase implies that protease activity can influence estuarine primary productivity and diagenetic processes involved in sediment $\mathrm{N}$ cycling. However, $\mathrm{NH}_{4}{ }^{+}$production also depended on the quality or availability of labile organic-N. Based on the heterogeneous composition of OM (Carlson 2002), it is difficult to understand the dynamics of N-cycling further without more detailed knowledge of the specific compound classes and individual molecules that comprise OM. In addition, more work is necessary to link microbe-molecule interactions to the dynamics of OM production. For example, different types of high molecular weight compounds are released by diatoms under different environmental and growth conditions (van Oijen et al. 2005, Wetz \& Wheeler 2007) and by distinct diatom species (Barofsky et al. 2010). The composition of dissolved OM from less studied but potentially significant and dynamic sources, such as viral lysis of bacterial cells (Banning et al. 2010) and exudates of $\mathrm{N}$ fixers (Webb et al. 2009), are not well defined.

The influence of bacterial proteases on $\mathrm{N}$ remineralization in estuarine sediments elucidated here is especially important in estuaries with small tidal amplitude and low freshwater inflow, where benthic regeneration is a significant source of nutrients to primary producers. These types of estuaries are common in south Texas, where low inflow rates have reduced allochthonous loading of nutrients and significant proportions of nutrients are supplied by nutrient recycling. For example, sediment regeneration supplied $90 \%$ of dissolved $\mathrm{N}$ to the phytoplankton community in Corpus Christi Bay and maintained relatively stable productivity during long periods of low river discharge (Flint et al. 1986).

Ammonium evolution presented in the current study represents the byproduct of anaerobic remineralization, since incubations were conducted in anoxic sediments to avoid $\mathrm{NH}_{4}^{+}$removal through microbial pathways such as nitrification coupled to denitrification. In addition, $\mathrm{NH}_{4}{ }^{+}$measurements were conducted only in the overlying water and did not account for the pool of $\mathrm{NH}_{4}{ }^{+}$adsorbed to sediment. This adsorbed pool can be a significant portion of the total inorganic-N pool, especially when the dissolved $\mathrm{NH}_{4}{ }^{+}$pool occurs at low concentrations (Blackburn 1979). It is therefore possible that a larger fraction of the protein added to sediment was regenerated as $\mathrm{NH}_{4}{ }^{+}$if the adsorbed fraction were considered in the mass balance calculations.

Hydrolysis rates sometimes occur faster than microbial uptake rates (Arnosti \& Repeta 1994, Bruchert \& Arnosti 2003). The time-averaged hydrolysis rate of $4 \mu \mathrm{M} \mathrm{h}^{-1}$ in $72 \mathrm{~h}(288 \mu \mathrm{M} / 72 \mathrm{~h})$ for casein-amended samples (Fig. 2) was high relative to the observed ammonium production rate of $1.03 \mu \mathrm{M} \mathrm{h} \mathrm{h}^{-1}$ (75 $\mu \mathrm{M}$ $\mathrm{NH}_{4}{ }^{+} / 72 \mathrm{~h}$ ) over the same period. Assuming no amino acid or $\mathrm{NH}_{4}{ }^{+}$assimilation, these results suggest that the potential supply rates of amino acids from enzymatic hydrolysis of protein were about 4 -fold higher than the bacterial $\mathrm{NH}_{4}^{+}$regeneration rates. This faster hydrolytic step resembles the relationship between hydrolysis of polysaccharides and microbial uptake and remineralization of oligosaccharides (Arnosti \& Repeta 1994). However, aminopeptidase 
hydrolysis not only produces amino acids, which are readily available for uptake, but also smaller protein molecules and polypeptides, which require further enzymatic action prior to microbial uptake. In addition, enzyme activities corresponded to the maximum potential rates, which may be faster than in situ rates of aminopeptidase activity. The direct increase in $\mathrm{NH}_{4}{ }^{+}$concentration with increasing protein content (Fig. 4) indicated that bacterial proteases hydrolyze casein to constituent amino acids, which can be metabolized by bacteria. The observed significant initial activity increase of aminopeptidase activity with time may have resulted from subtle disturbances of the sediment. Abrasion of sediment grains or damaged microbial cell walls could have enhanced enzymatic activity due to labile organic compounds released from mineral surfaces (Porter et al. 2006).

The decrease in aminopeptidase activity detected in all treatments may relate to a decrease in labile enzyme substrate. A similar direct relationship between protease activity and substrate concentration occurred in estuarine sediments (Mayer 1989). Substrate dependence may explain the return of enzyme activity to initial levels in both control and polyphenol treatments and the delayed activity decrease in the casein-treated sediments. The lower decrease in activity compared to control samples after $72 \mathrm{~h}$ could relate to casein or hydrolysable peptides remaining in the sediment.

Regression analysis was consistent with the theoretical hypothesis that $\mathrm{NH}_{4}{ }^{+}$concentrations were a function of enzyme activity. Assessment of the strength of the linear relationship showed that $\mathrm{NH}_{4}{ }^{+}$ concentration correlated positively with aminopeptidase activity in controls $(r=0.86, p<0.01)$, caseinenriched $(\mathrm{r}=0.89, \mathrm{p}<0.01)$, and casein plus polyphenol treatments $(\mathrm{r}=0.71, \mathrm{p}<0.01)$ over the first $72 \mathrm{~h}$. A causal relationship between $\mathrm{NH}_{4}^{+}$concentration and aminopeptidase activity could be inferred from the casein-enriched samples. The induced increases in aminopeptidase activity by casein were reflected by proportionally higher $\mathrm{NH}_{4}{ }^{+}$concentrations. The regression coefficient of determination $\left(\mathrm{r}^{2}\right)$ suggested that $89 \%$ of the variation in $\mathrm{NH}_{4}{ }^{+}$concentration in casein-enriched samples could be explained by aminopeptidase activity.

\section{Inhibition of aminopeptidase activity and $\mathrm{NH}_{4}{ }^{+}$ production rates by polyphenol}

A second important result of this work is the observed inhibition of aminopeptidase by polyphe- nol, which also caused reductions in $\mathrm{NH}_{4}{ }^{+}$production rates in samples where tannic acid was added in combination with casein. This result indicates that the remineralization process is affected both by the OM source and the presence of enzyme inhibitors. Since phenolic compounds are derived primarily from terrestrial vascular plants, detrital material high in polyphenols may reach the sediments primarily after rain events that increase river discharge rates. Tannic acid inhibition on leucine aminopeptidase, however, was not as significant at background levels of OM content or quality (i.e. control treatments), which consequently had little impact on $\mathrm{NH}_{4}{ }^{+}$production. One of the reasons for the low background $\mathrm{NH}_{4}{ }^{+}$production, and the lack of major inhibition in experiments without added casein, is that the typical supply rates of labile proteins in subsurface sediments may be low or sporadic compared to casein in natural sediments, relative to those caused by the spiking of high levels of casein in our experiments. For example, the results after casein additions represent 'potential' rates of $\mathrm{NH}_{4}{ }^{+}$production and enzyme inhibition, rather than 'actual' rates. The $\mathrm{NH}_{4}{ }^{+}$production rates from labile proteins depend on the supply rates of labile proteins and on the enzymatic breakdown rates of the more stable proteins, which are likely the only ones remaining in typical sediments and decomposed at a low rate. In contrast, the labile constituents are removed rapidly after they enter the sediments. If the supply rates of labile proteins are low or sporadic, the enzymatic breakdown of less labile proteins remaining in the sediments would be low and respond differently to the addition of inhibitor than occurred after the addition of the labile casein alone. We surmise that the lack of enzyme inhibition observed in the second experiment may also have resulted from the presence of amino peptidases that were not sensitive to the polyphenol mode of action. Structurally different aminopeptidase enzymes with unique responses to polyphenol exposure likely coexist in nature. Polyphenols inhibit the action of enzymes by binding to amino acids in the protein residues, which in turn could lead to structural changes in the enzyme protein (Soares et al. 2007) and affect activity. For example, tannins bind to free $-\mathrm{NH}_{2}$ groups of proteins (Rawel et al. 2005). However, this mechanism may not inhibit all enzyme activity. In addition, diverse groups of proteases have variable structures and different hydrolytic abilities. A possible example is leucine-aminopeptidase, which is a metallprotease (Mikiko et al. 2006) and may respond differently than non-metallic proteases. 
The method of estimating enzyme activity used in the present study may have also influenced the results by measuring the 'potential' rather than 'actual' enzyme activity levels. Polyphenol interactions with aminopeptidase usually do not reduce the maximum activity of the enzymes, but can modify the enzyme's actual affinity to the substrates - as quantified by the kinetic parameter Km. Polyphenol may have decreased enzyme affinity and competed with the enzyme substrate. This competition was suggested, in the treatment with combined casein and polyphenol, by the increase of enzyme activity above the control treatments but below the level of sediment treated with casein alone. The added polyphenol may have out-competed the natural substrate and inhibited activity, if the released enzyme in the collected sediment had a high number of active sites in combination with a high content of natural substrate available in the sediment. Complexation of tannins with carbohydrates may also have reduced the ability of the added tannin to react with the enzyme. Some bacteria increase production of extracellular polysaccharide in response to tannins (Brooker et al. 1999). Although this response has not been demonstrated in marine sediments, it offers a potential mechanism for microorganisms to maintain metabolic activities in estuarine sediments exposed to riverine input of plant products.

\section{CONCLUSIONS}

Aminopeptidase activity and $\mathrm{NH}_{4}{ }^{+}$production rates in Texas subsurface coastal sediments related directly to concentrations of added protein (casein), a labile organic-N source. This observed high 'potential' aminopeptidase activity implies that enzyme degradation of complex proteins or other organic-N compounds is an important process in these sediments. An interesting new finding is that an aminopeptidase inhibitor, tannic acid (representing a typical polyphenol commonly transported into coastal systems), significantly reduced the percentage of $\mathrm{NH}_{4}^{+}$produced in experimental samples with added casein. This effect was less pronounced in control samples without added casein, a result that implies that the supply rates or compositions of the natural organic-N substrates were likely different from those of the added casein, even though the rapid and immediate degradation rates of the added casein by aminopeptidases implies similarities to naturally available substrates. The lack of enzyme inhibition may also have resulted from the presence of aminopeptidase insensitive to polyphenol inhibition or been affected by the measurement methodology. Thus, while protease activity on active organic-N compounds undoubtedly influence sediment $\mathrm{N}$-cycling processes in coastal sediments that may be decreased by enzyme inhibitors, the interactions of these processes likely depend on processes that affect the supply rates, composition, and/or susceptibility to enzymatic degradation of the organic-N substrate compounds that are supplied or degraded at different rates in nature. More work on these interactions is needed to understand the importance of aminopeptidase on N-cycling at different sites and depths in coastal sediments. Detailed knowledge of the supply and degradation rates, specific compound classes, and individual molecules that comprise the active organic-N compounds at different sediment depths, as well as the importance of natural enzyme inhibitors, is needed to provide insights on the importance of enzymatic processes that control the degree of $\mathrm{NH}_{4}{ }^{+}$production from proteins and other high molecular weight organic-N compounds in coastal sediments.

Acknowledgements. The authors thank the Mission Aransas National Estuarine Research Reserve staff for boat and logistics sample-collection support, Tracy Villareal, Carol Arnosti, Henrietta Edmonds, and Dong Ha Min for research and writing suggestions, and 2 anonymous reviewers for constructive recommendations on the submitted manuscript. Financial support was provided by The University of Texas at Austin College of Natural Sciences via startup funds for T.K.P and by The University of Texas Marine Science Institute via a Lund Fellowship awarded to A.C.S.

\section{LITERATURE CITED}

An S, Gardner WS (2002) Dissimilatory nitrate reduction to ammonium (DNRA) as a nitrogen link, versus denitrification as a sink in a shallow estuary (Laguna Madre/Baffin Bay, Texas). Mar Ecol Prog Ser 237:41-50

Arnosti C (2011) Microbial extracellular enzymes and the marine carbon cycle. Ann Rev Mar Sci 3:401-425

Arnosti C, Repeta DJ (1994) Extracellular enzyme activity in anaerobic bacterial cultures: evidence of pullulanase activity among mesophilic marine bacteria. Appl Environ Microbiol 60:840-846

Banning EC, Casciotti KL, Kujawinski EB (2010) Novel strains isolated from a coastal aquifer suggest a predatory role for Flavobacteria. FEMS Microbiol Ecol 73: 254-270

> Barofsky A, Simonelli P, Vidoudez C, Troedsson C, Nejstgaard JC, Jakobsen HH, Pohnert G (2010) Growth phase of the diatom Skeletonema marinoi influences the metabolic profile of the cells and the selective feeding of the copepod Calanus spp. J Plankton Res 32:263-272

> Berman T, Bronk DA (2003) Dissolved organic nitrogen: a dynamic participant in aquatic ecosystems. Aquat Microb Ecol 31:279-305 
Bianchi TS, Pennock JR, Twiley RR (1999) Biogeochemistry of the Gulf of Mexico estuaries. John Wiley \& Sons, New York, NY

Blackburn TH (1979) Method for measuring rates of $\mathrm{NH}(4)$ turnover in anoxic marine sediments, using a $15 \mathrm{~N}-\mathrm{NH}(4)$ dilution technique. Appl Environ Microbiol 37:760-765

Blackburn TH (1991) Accumulation and regeneration: processes at the benthic boundary layer. In: Mantoura RFC, Martin JM, Wollast R (eds) Ocean margin processes in global change. Wiley, New York, NY, p 181-195

Blackburn TH, Henriksen K (1983) Nitrogen cycling in different types of sediment from Danish waters. Limnol Oceanogr 28:477-493

Boyer JN, Stanley DW, Christian RR, Rizzo WM (1988) Modulation of nitrogen loading impacts within an estuary. In: Lyke WL, Hoban TJ (eds) Proceedings N.C. Amer. Water Resources Assoc., Symposium on coastal water resources. AWRA Technical Publ. Series TPS-88-1, AWRA, Bethesda, MD, p 165-176

> Boynton WR, Kemp WM (1985) Nutrient regeneration oxygen consumption by sediments along an estuarine salinity gradient. Mar Ecol Prog Ser 23:45-55

Brooker JD, O'Donovan L, Skene S, Sellick G (1999) Mechanisms of tannin resistance and detoxication in the rumen. In: Bell CR, Brylinsky M, Johnson-Green P (eds) Microbial biosystems: new frontiers. Proceedings of the 8th international symposium on microbial ecology. Atlantic Canada Society for Microbial Ecology, Halifax

Bruchert V, Arnosti C (2003) Anaerobic carbon transformation: experimental studies with flow-through cells. Mar Chem 80:171-183

Carlson CA (2002) Production and removal processes. In: Hansell DA, Carlson CA (eds) Biogeochemistry of marine dissolved organic matter. Academic Press, Amsterdam, p 91-139

> Cowan JL, Boynton WR (1996) Sediment-water oxygen and nutrient exchanges along the longitudinal axis of Chesapeake Bay: seasonal patterns, controlling factors and ecological differences. Estuaries 19:562-580

$>$ Cowie GL, Hedges JI (1992) Sources and reactivities of amino acids in a coastal marine sediment. Limnol Oceanogr 37:703-724

> D'Elia CF, Sanders JG, Boyton WR (1986) Nutrient enrichment studies in a coastal plain estuary: phytoplankton growth in large-scale, continuous cultures. Can J Fish Aquat Sci 43:397-406

Fisher RR, Carlson PR, Barber RT (1982) Sediment nutrient regeneration in three North Carolina estuaries. Estuar Coast Shelf Sci 14:101-116

Flint RW, Powell GL, Kalke RD (1986) Ecological effects from the balance between new and recycled nitrogen in Texas coastal waters. Estuaries 9(4A):284-294

> Galloway JN, Dentener FJ, Capone DG, Boyer EW and others (2004) Nitrogen cycles: past, present, and future. Biogeochemistry 70:153-226

> Gardner WS, Cotner JB, Herche L (1993) Chromatographic measurement of nitrogen mineralization rates in marine coastal waters. Mar Ecol Prog Ser 93:65-73

Gardner WS, Benner R, Amon R, Cotner J, Cavaletto J, Johnson J (1996) Effects of high molecular weight dissolved organic matter on the nitrogen dynamics on the Mississippi River plume. Mar Ecol Prog Ser 133: 287-297

Gardner WS, McCarthy MJ, An S, Sodolev D, Sell S, Brock D (2006) Nitrogen fixation and dissimilatory nitrate reduction to ammonium (DNRA) support nitrogen dynamics in Texas estuaries. Limnol Oceanogr 51: 558-568

Hansen LS, Blackburn TH (1992) Mineralization budgets in sediment microcosms: effect of the infauna and anoxic conditions. FEMS Microbiol Lett 102:33-43

> Hansen LS, Holmer M, Blackburn TH (1993) Mineralization of organic nitrogen and carbon (fish food) added to anoxic sediment microcosms: role of sulfate reduction. Mar Ecol Prog Ser 102:199-204

Henriksen K, Kemp WM (1988) Nitrification in estuarine and coastal marine sediments. In: Blackburn TH, Sorensen J (eds) Nitrogen cycling in marine environments. John Wiley, New York, NY, p 207-249

> Hoppe HG (1983) Significance of exoenzymatic activities in the ecology of brackish water: measurements by means of methylumbelliferyl-substrates. Mar Ecol Prog Ser 11: 299-308

> Jacobson ME, Mackin JE, Capone DG (1987) Ammonium production in sediments inhibited with molybdate: implications for sources of ammonium in anoxic marine sediments. Appl Environ Microbiol 53:2435-2439

Jaffe DA (2000) The nitrogen cycle. In: Jacobson MC, Charlson RJ, Rhode H, Orians GH (eds) Earth system science-from biogeochemical cycles to global change. Academic Press, New York, NY, p 263-284

Kemp WM, Boynton WR (1984) Spatial and temporal coupling of nutrient inputs to estuarine primary production: the role of particulate transport and decomposition. Bull Mar Sci 35:522-535

> Landen A, Hall POJ (1998) Seasonal variation of dissolved and adsorbed amino acids and ammonium in near-shore marine sediment. Mar Ecol Prog Ser 170:67-84

Leigh JA, Dodsworth JA (2007) Nitrogen regulation in Bacteria and Archaea. Annu Rev Microbiol 61:349-377

Matsui M, Fowler JH, Walling L (2006) Leucine aminopeptidases: diversity in structure and function. Biol Chem 387 : 1535-1544

Mayer LM (1989) Extracellular proteolytic enzyme activity in sediments of an intertidal mudflat. Limnol Oceanogr 34:973-981

McCarthy MJ, McNeal KS, Morse JW, Gardner WS (2008) Bottom-water hypoxia effects on sediment-water interface nitrogen transformations in a seasonally hypoxic, shallow bay (Corpus Christi Bay, TX, USA) Estuar Coasts 31(3):521-531

Nielsen SL, Sand-Jensen K, Borum J, Geertz-Hansen O (2002) Phytoplankton, nutrients, and transparency in Danish coastal waters. Estuaries 25:930-937

Pantoja S, Lee C (1999) Peptide decomposition by extracellular hydrolysis in coastal seawater and salt march sediment. Mar Chem 63:273-291

Pantoja S, Lee C, Marecek JF (1997) Hydrolysis of peptides in seawater and sediment. Mar Chem 57:25-40

Parsons TR, Matia Y, Lalli C (1984) A manual of chemical and biological methods for seawater analysis. Pergamon, New York, NY

> Paerl HW, Dyble J, Twomey L, Pinkney JL, Nelson J, Kerkhof L (2002) Characterizing man-made and natural modifications of microbial diversity and activity in coastal ecosystems. Antonie van Leeuwenhoek 81:487-507

Porter TE, Owens MS, Cornwell JC (2006) Effect of sediment manipulation on the biochemistry of experimental sediment systems. J Coast Res 22:1539-1551

Rawel HM, Meidtner K, Kroll J (2005) Binding of selected 
phenolic compounds to proteins. J Agric Food Chem 53: 4228-4235

Soares S, Mateus N, De Freitas V (2007) Interaction of different polyphenols with bovine serum albumin (BSA) and human salivary alpha-amylase (HSA) by fluorescence quenching. J Agric Food Chem 55:6726-6735

Thurman EM (1985) Organic geochemistry of natural waters. Martinus Nijhof/Dr. W. Junk Publishers, Boston, MA, p 363-440

> van Alstyne KL (1995) A comparison of three methods for quantifying brown algal polyphenolic compounds. J Chem Ecol 21:45-58

van Oijen T, Veldhuis MJW, Gorbunov MY, Nishioka J, van Leeuwe MA, de Baar HJW (2005) Enhanced carbohydrate production by Southern Ocean phytoplankton in response to in situ iron fertilization. Mar Chem 93:33-52

Warnken KW, Gill GA, Santschi PH, Griffin LL (2000) Ben-

Editorial responsibility: Patricia Glibert, Cambridge, Maryland, USA thic exchange of nutrients in Galveston Bay, Texas. Estuaries 23:647-661

Webb EA, Ehrenreich IM, Brown SL, Valois FW, Waterbury JB (2009) Phenotypic and genotypic characterization of multiple strains of the diazotrophic cyanobacterium, Crocosphaera watsonii, isolated from the open ocean. Environ Microbiol 11:338-348

Wetz MS, Wheeler PA (2007) Release of dissolved organic matter by coastal diatoms. Limnol Oceanogr 52:798-807

Wollast R (1991) The coastal organic carbon cycle: fluxes, sources, and sinks. In: Mantoura RFC, Martin JM, Wollast $\mathrm{R}$ (eds) Ocean margin processes in global change. John Wiley and Sons, New York, NY, p 365-381

Wollast R (1993) Interactions in estuaries and coastal waters. In: Bolin B \& Cook RB (eds) The major biogeochemical cycles and their interactions. John Wiley, Chichester, p 385-409

Submitted: April 12, 2011; Accepted: September 19, 2011 Proofs received from author(s): November 29, 2011 